Article

\title{
Understanding Barriers in Indian Ocean Tuna Commission Allocation Negotiations on Fishing Opportunities
}

\author{
Hussain Sinan *(D) and Megan Bailey \\ Marine Affairs Program, Dalhousie University, Halifax, NS B3H 4R2, Canada; megan.bailey@dal.ca \\ * Correspondence: hussain.sinan@dal.ca
}

Received: 24 June 2020; Accepted: 11 August 2020; Published: 18 August 2020

\begin{abstract}
Tuna Regional Fisheries Management Organizations (RFMOs) have been given an arduous mandate under the legal framework of the United Nations Fish Stocks Agreement. Member states with different interests and objectives are required to cooperate and collaborate on the conservation and management of tuna and tuna-like species, which includes the allocation of fishing opportunities. It is well understood that the main RFMO allocation disagreements are the inability to agree on a total allowable catch, the lack of willingness to accept new members, disagreement on who should bear the conservation burden, and non-compliance with national allocations owning to perceived inequities. Addressing these elements is crucial for any organization if it is to sustain its credibility stability and legitimacy. This paper identifies additional barriers facing an equitable allocation process at the Indian Ocean Tuna Commission (IOTC). These challenges are multi-faceted and include institutional, political, and scientific barriers in the ongoing allocation negotiations, and further inhibit effective negotiation and resolution adoption as a whole. After almost 10 years of negotiations, the process has progressed little, and without agreement on these barriers it will be a challenge to adopt a stable systematic allocation process.
\end{abstract}

Keywords: fishery management; equity; tuna governance; Indian Ocean Tuna Commission; tuna allocation; marine policy

\section{Introduction}

The Indian Ocean Tuna Commission (IOTC) is one of the five tuna Regional Fisheries Management Organizations (RFMOs) established under the framework of the United Nations Convention on the Law of the Sea (UNCLOS) and its implementing agreement-The United Nations Agreement for the Implementation of the Provisions of the United Nations Convention on the Law of the Sea of 10 December 1982 relating to the Conservation and Management of Straddling Fish Stocks and Highly Migratory Fish Stocks (UNFSA). These legal instruments have various provisions to guide RFMOs in sustaining institutional credibility, stability, and legitimacy in their decision-making processes. While RFMOs have the right to rule on the management of the stocks, external perceptions of legitimacy and credibility matter to ensure the stability of the institution [1]. The mechanisms to achieve stability are based on the reliability, sufficiency, and confidence of its member state decision-making processes [2]. Multilateral institutions will only thrive if they are viewed as legitimate by the general public, which is in part linked to the need for credible decisions only attainable when RFMO delegates have sufficient knowledge to interpret and validate scientific and technical information [3]. Furthermore, fair and equitable decision-making among other elements such as enforcement, compliance, adaptivity, membership, and transparency are certain elements for any RFMO to perform effectively. 
One of the most fundamental decisions to be made for natural resource governance is how resources are allocated among individuals [4]. The success of an allocation process has the potential to permeate almost all other decisions taken by RFMO members and thus has the potential to either secure or to undermine the credibility and legitimacy linked with the realization of the conservation and management mandate [5]. However, regulating highly migratory species such as tuna, one of the most tradable fish in the world, is a contentious issue, mainly due to economic, institutional, and political factors, including competition in trade [6]; the transboundary nature of tuna stocks and their presence, both in coastal waters and in areas beyond national jurisdiction [7]; species distribution; gear complexities [7,8]; scientific uncertainties; and geopolitics [9]. Additionally, due to their economic and employment significance and importance to food security [10], members protect their own economic and political interests within a scientific framework during negotiations in RFMOs $[6,11]$. These differences are compounded with the complexity and ambiguity of international legal instruments with regards to sovereignty over tuna resources. Together, these complexities create a fundamental barrier in the negotiations for a systematic allocation model by all the RFMOs [12], and the Indian Ocean Tuna Commission (IOTC) is no exception.

The IOTC was established in 1993 as an Article 14 body of the Food and Agriculture Organization of the United Nations (FAO) Constitution (under the provisions of Article XIV of the FAO Constitution, the FAO Council may approve and submit to Member Nations agreements concerning questions relating to food and agriculture which are of particular interest to Member Nations of geographical areas specified in such agreements). For the eyes of FAO, IOTC is another project administered by FAO. IOTC is the only tuna RFMO to be under the framework of FAO and covers ocean space from eastern South Africa to eastern Australia and Indonesia. FAO was instrumental in the development of IOTC, and article 14 was the most favorable mechanism to retain IOTC within the FAO framework at that time. Currently, there are 31 member states in the IOTC, 22 of which are coastal states (i.e., countries whose waters are found within the convention area). Unlike in the other oceans in the world where industrial operations dominate, artisanal fisheries take a greater proportion of the tuna catch in the Indian Ocean [13], and there is huge variation among the benefits that the coastal states accrue from tuna resources. From 2014 to 2018, around 94\% of the catch of the three tropical tuna species (skipjack tuna, yellowfin tuna, and bigeye tuna) in the Indian Ocean was caught by 11 members of the 31 with IOTC membership (the European Union is a member of the IOTC. Under EU membership, France, Italy, Portugal, Spain, the United Kingdom, and Mayotte vessels fish in the Indian Ocean). In the spirit of promoting "optimum utilization", under Article 62 of UNCLOS, some coastal states have permitted other states to fish for the resources within their Exclusive Economic Zone (EEZ) through fishing access agreements, mainly due to a lack of domestic fishing capacity. For example, the European Union (EU) has tuna access agreements with Madagascar, Seychelles, and Mauritius in the Indian Ocean [14]. The European Commission also allows the tuna processed in these countries to be imported into Europe tax-free. In addition, Japan, China, and South Korea also have access agreements, but these agreements are not publicly available [15]. Furthermore, the canneries in the Indian Ocean also process and add value to the catch. Thailand, Indonesia, Iran, Oman, Seychelles, Mauritius, Maldives, and Madagascar all have canneries that process skipjack and yellowfin tuna. Besides canning, the major fishing nations in the Indian Ocean also export their fish to the sashimi market in Japan and to fresh and frozen tuna markets in the EU and the USA. At the same time, some of the countries in the Indian Ocean rely heavily on tuna species for local consumption. For example, Maldivians consume on average $163 \mathrm{~kg}$ of pelagic fish per year [16], about eight times the global average. Countries that catch the majority of tuna in the Indian Ocean are also large consumers of pelagic fish and are above the global average of $6.9 \mathrm{~kg}$ per capita per year [16]. Finally, the entire EEZ and coastal waters of the British Indian Ocean Territory is declared a Marine Protected Area [17], suggesting that conservation and not consumption is also a priority for some members.

Like other tuna RFMOs [12], the IOTC has been working on developing an allocation framework. These discussions on allocating fishing opportunities (i.e., typically a proportion of the total allowable 
catch in a given year) to IOTC member countries started in response to the organizations' first performance review [18]. The process was later formalized through Resolution 10/01 after the scientific committee recommended taking decisive steps to reduce the overexploitation of yellowfin tuna and bigeye tuna in 2010 (Resolution 10/01). Since then, the negotiations have progressed both in the Technical Committee on Allocation Criteria (TCAC) and in the commission. The TCAC was established to solely discuss the technicalities of the allocation process, but a considerable time of the commission plenary has also been devoted to discussing the matter in length over the last decade. However, the negotiations have been slow to progress, with a substantiable divide between member states [19]. While these negotiations continue, tuna stocks continue to be heavily fished. Since 2014, yellowfin tuna is considered biologically overfished, with overfishing occurring; in 2019, bigeye tuna and albacore were both considered overfished; and skipjack tuna was fished by more than $30 \%$ of the harvest control limit in 2018 [20]. As fishing pressure remains high and stocks are not being given a chance to rebuild, the calls to reach an allocation agreement as soon as possible have gained traction [21-23]. So, how can the tension between the institution's own calls for an agreement with a lack of practical progress towards cooperation be explained?

Lodge et al. [5] highlighted that the main difficulties RFMOs encounter in allocation mechanisms are (i) the inability to agree on a total allowable catch because of the concomitant limits it would impose on their national fleets, (ii) an inability to accommodate new members with an interest in fishing within allocation regimes, and (iii) non-compliance with national allocations owning to perceived inequalities. While all of these challenges are true for tuna RFMOs, here we explore the history of the allocation process at the IOTC and identify the additional barriers that have impeded consensus in the context of a fishery that is worth more than 4.76 billion US dollars [24]. Our contribution is two-fold: we first provide a brief overview of the IOTC allocation process to date, and subsequently expand on the current limitations affecting progress. Understanding these barriers is critical in creating an effective allocation process not only in theory but in practice, and one that will help to contribute to the legitimacy, credibility, and thus stability of the RFMO.

To develop this paper, the authors attended IOTC meetings as a country delegate (2017-2019, first author) and Non-governmental Organization observer (2018, second author). In the case of the first author, TCAC meetings were also attended from 2018 and 2019. During the 2018 IOTC meeting, the authors kept notes and had daily debriefings to discuss the progress and process. Specifically, the interventions made by member states in the IOTC's TCAC and commission meetings in 2018 and 2019 were observed in order to identify and categorize the barriers to decision-making. These were than correlated with the findings from the IOTC's performance review and the reports of the IOTC commission and subsidiary bodies. The barriers that were identified were then grouped based on their commonalities.

\section{Allocation Negotiations in the IOTC}

When formal allocation negotiations began in 2010, there were five distinct proposals by Indonesia, Seychelles, European Union, Iran, and the Republic of Korea. Japan and Sri Lanka also submitted proposals in the earlier meetings [25]. Focused discussions on establishing guiding principles and criteria that would govern a quota allocation system occurred in the first three TCAC meetings. At the outset of the allocation negotiations, the proposals and subsequent negotiations were focused on establishing a systematic (formulae-based) allocation system. A group of like-minded coastal states grouped under the tag of G16 (named after Article XVI of the IOTC agreement, acknowledging the sovereign rights of coastal states over the living resources in their EEZs) proposed a list of criteria, as did the EU and France Overseas Territories (France OT) (Table 1). After five meetings of TCAC in over 10 years, two proposals still remain on the negotiation table-one from the Maldives with support from 10 other members, and a proposal from the European Union [26]. The Maldivian delegation tabled their proposal in 2017, 2018, and in 2019 in the commission to expedite the process. However, there has still been little progress made, and tensions in reaching an agreement remain. 
Table 1. Guiding principles proposed by the G16 group of like-minded coastal states and European Union and France Overseas Territories (OT) in the third allocation meeting [27].

\begin{tabular}{|c|c|c|}
\hline General Principles & G16 Coastal States & European Union and France OT \\
\hline \multirow[b]{2}{*}{ Sustainability } & Sustainable fishery. & Ensure the sustainable utilization of the resources. \\
\hline & & $\begin{array}{l}\text { Consider degree of sustainability of fishing methods } \\
\text { with respect to ecosystem approach. }\end{array}$ \\
\hline \multirow{2}{*}{ Rights under international law } & $\begin{array}{l}\text { Exclusive rights of the Indian } \\
\text { Ocean coastal states in their EEZs. }\end{array}$ & $\begin{array}{l}\text { Recognize the rights of both Indian Ocean coastal } \\
\text { states and distant water fishing nations. }\end{array}$ \\
\hline & $\begin{array}{l}\text { Recognize and take account of the } \\
\text { rights of all CPCs on the high seas. }\end{array}$ & \\
\hline \multirow[b]{2}{*}{ Food security } & Food and livelihood security. & $\begin{array}{l}\text { Consider food security issues, which shall include } \\
\text { not only the catch of tuna and tuna-like species, but } \\
\text { also their processing and trade. }\end{array}$ \\
\hline & & $\begin{array}{l}\text { Consider socio-economic factors, such as the } \\
\text { dependency of Indian Ocean coastal state economies, } \\
\text { for the livelihood of their local communities on tuna } \\
\text { and tuna-like fisheries and investments made in the } \\
\text { tuna sector. }\end{array}$ \\
\hline Equity & $\begin{array}{l}\text { Equitable utilization and } \\
\text { conservation of the resources. }\end{array}$ & $\begin{array}{l}\text { Allocate fair and equitable fishing opportunities to } \\
\text { all participants. }\end{array}$ \\
\hline Differentiation for coastal states & $\begin{array}{l}\text { Special consideration for small, } \\
\text { vulnerable economies and } \\
\text { developing coastal states of the } \\
\text { Indian Ocean. }\end{array}$ & $\begin{array}{l}\text { Take into account the aspirations of Indian Ocean } \\
\text { coastal states, including to develop their fishing } \\
\text { opportunities. }\end{array}$ \\
\hline Trade & & $\begin{array}{l}\text { Consider the weight of imports of tuna products on } \\
\text { economies and the global consumption of tuna } \\
\text { products of contracting parties. }\end{array}$ \\
\hline \multirow[b]{2}{*}{ Compliance } & & Reflect the compliance record/status of eachmember. \\
\hline & & $\begin{array}{l}\text { Enforce effective rules against Illegal, Unreported } \\
\text { and Unregulated (IUU) fishing. }\end{array}$ \\
\hline Transferability & & Authorize the transferability (lease) of allocations. \\
\hline Governance & $\begin{array}{l}\text { Tuna management process shall be } \\
\text { consistent with international laws. }\end{array}$ & \\
\hline
\end{tabular}

While there is noticeable agreement on some of the principles and systematic approaches (Table 1), significant differences still remain between the two proposals. One of the critical issues that has persisted for the last 10 years of the negotiations has been the attribution of historical catches in the EEZs of the coastal states by foreign-flagged vessels $[19,28]$. Based on interventions made in the IOTC plenary, coastal states maintain their position that the fish caught in their waters should be attributed as part of their historical catch, irrespective of the flag state that caught the fish. These coastal states consistently stated that they will not compromise on that matter. However, the EU, Japan, Korea, and China also consistently argued in the IOTC plenary that the historical catches should be attributed based on the flag state, as it was paid for and fished by their fishing vessels. In the spirit of compromise, in the 2018 TCAC meeting the Distant Water Fishing Nations (DWFN)s offered a 10\% attribution of catches made in the coastal waters to the coastal states. However, the proposal has been firmly rejected by the coastal states in the last two TCAC meetings and subsequent commission meetings.

For many states, the different principles articulated in the two proposals remain abstract in terms of their practical implication for catches and the attending benefits that the catch brings. In 2019, as discussed and agreed upon at the 2018 meeting, a consultant was hired to develop allocation simulations to provide catch estimates under the two different allocation proposals. However, the negotiations still remain tense and inconclusive, even though countries now have a tangible potential catch allocation to work with. The tensions and the divisions in allocation negotiations have spilled over into other discussions in the commission and vice versa, and it therefore remains important to identify and suggest ways around the key institutional, political, and scientific barriers limiting cooperation. 


\section{Institutional Barriers}

\subsection{Relationship between FAO and IOTC}

The IOTC evolved through the FAO system. Recognizing the lack of inadequate fisheries bodies in the Indian Ocean, under FAO Council Resolution 2/48, the FAO established the Indian Ocean Fisheries Commission (IOFC) in 1969 [29]. At the first session of the IOFC, it established a committee for the management of Indian Ocean Tuna to consider management measures for tuna stocks. However, the discussions to establish a separate body, such as the two other tuna RFMOs in existence at that time-International Commission for the Conservation of Atlantic Tunas (ICCAT) and Inter-American Tropical Tuna Commission (IATTC)-began right from the first meeting of the IOFC. There were discussions at that time as well to establish a separate body outside the framework of the FAO, but apparently it was decided that, due to the complex political considerations, it would need to be a long-term goal. Moreover, the member states felt that they needed the financial and technical support of the FAO in the initial development of the organization [30]. The draft agreement was formulated by the FAO, reflecting the negotiations and giving a greater autonomy to IOTC compared to other Article 14 bodies.

The IOTC is the only tuna RFMO that is an FAO body, and the strained relationship between the two institutions has posed explicit challenges in fulfilling the mandate of the organization, including allocation negotiations. IOTC member states have to rely on the FAO rules of procedure to hire staff, administration, and finance, instead of the rules and procedures adopted by the member states of the IOTC. In 2006, the commission decided to explore ways to change the relationship between the IOTC and the FAO [31] due to frustrations with the inability to address the integration of fishing entities, the perceived interference of the FAO in the transparency of IOTC governance without much added value, the lack of flexibility and autonomy operating in the FAO system, and the increased cost of operating under the FAO system [32]. However, after the terms of a "divorce" were agreed to in a working session, the director general of FAO blocked the documents being circulated among member states, preventing it from being discussed in the IOTC commission [33]. FAO's intervention in the matter has been argued to be unconstitutional by many member states [33].

The resignation of the IOTC executive secretary in 2015 [34] and the election of a new executive secretary reignited these disputes. The FAO proposed to follow its standard procedures for the appointment of the new executive secretary instead of the rules of procedure of the IOTC, agreed to and adopted by the FAO and the IOTC. Many members opposed the decision [35] (in a written statement, many members stated "in seeking to address these issues the FAO has disregarded the agreed, legitimate rules established by this Commission and you have asked this Commission to join you in disregarding our own rules of procedure. We do not take departure from our agreed Rules of Procedure lightly. It sends the wrong signal to member States and the rest of the world about IOTC's commitment to the rules and measures it has passed"), and without any progress on the issue for the next two years, the FAO and IOTC members agreed to appoint an executive secretary according to an exceptional procedure under the instruction of the FAO council based on the FAOs rules and procedures. The commission also agreed to work with the FAO to revise the IOTC rules of procedure, considering FAO's concerns through a working group [21]. However, FAO has rejected the revised amendments by the working group, and the matter continues to impede the work of the commission.

Without a resolution to the difficult relationship between the FAO and the IOTC, the tuna RFMO is almost crippled to fulfil its objectives. The organization cannot accept funds from external sources, cannot invite fishing entities to participate, and on top of this has to pay the FAO for its services. The commission hired a consultant to draft a modernized IOTC agreement, as advised in the second performance review [36]. These amendments include modern fishery management practices, including a better reflection of the UNFSA and compliance agreement [37]. However, the commission could not even agree to discuss the amendments due to the disagreements over the relationship of the IOTC and the FAO [23]. Despite these inconveniences and interferences, some countries opt to remain, mainly 
due to the perceived security of being in the FAO framework and the FAO's ability to assist if things go wrong. Furthermore, member states also have to take into account FAO's assistance in fishery development and management projects, and in the decision-making process. An allocation framework in an RFMO is supposed to provide the stability of the fishery to its members [5], yet it remains hard to envision how stable internal mechanisms will be possible with the overall organizational instability.

\subsection{Time-Gap between Data Reporting and Decision-Making Processes}

With the continual decline in fish stock abundance and increased fishing pressure present throughout the Indian Ocean, it is evident that another institutional barrier in the decision-making processes within the IOTC is the time-gap between data reporting, stock assessments, and scientific analysis and the decision-making processes. Under the current rules adopted by the commission, decisions can only be made based on the data of fishing activities that occurred two years previous to the decision-making year. Furthermore, the adopted measures come into force after 120 days. If a member state has objected to the measure within those 120 days, an additional 60 days is given before the measure comes into force [38].

The issues arising from this "time-gap" were evident in the yellowfin tuna reduction measures adopted by the commission to mitigate the overfishing of the stock. In 2016, the IOTC members decided to take measures to reduce yellowfin tuna catches based on the scientific committee's advice (based on 2014 data, as shown in Figure 1). One of the measures under Resolution 16/01 adopted in 2016 was for the purse seine flag states, with an over 5000 MT catch of yellowfin tuna to reduce their catches by $15 \%$ compared to the 2014 levels (IOTC, 2015). However, almost a year later in 2017, Seychelles submitted a letter stating that its fishing industry would collapse if the measure was to be implemented and requested to change their base year from 2014 to 2015 [39]. This was due to the fact that in 2014 the Seychelles purse seine fleet had fished 25,065 MT of yellowfin tuna, and in 2015 without a measure in place it had already fished 40,907 MT of yellowfin tuna. If Seychelles were to reduce its yellowfin tuna catch according to the measure, they would have to reduce it to $21,387 \mathrm{MT}$ (15\% reduction in the of 25,065 MT of yellowfin tuna caught in 2014), which is around $47 \%$ compared to the 2015 levels. The commission in 2017 agreed to take onboard Seychelles' concerns and revised the measure (IOTC Resolution 17/01). A similar trend was observed in the 2019 commission meeting. Additionally, Mauritius had developed its purse seine fishery beyond the allowable threshold as per the measure (increased its catches to 7,681 MT in 2017); the commission allowed Mauritius to reduce their purse seine catches from the 2018 levels, even though they did not submit their data for the 2018 levels at that time [23].

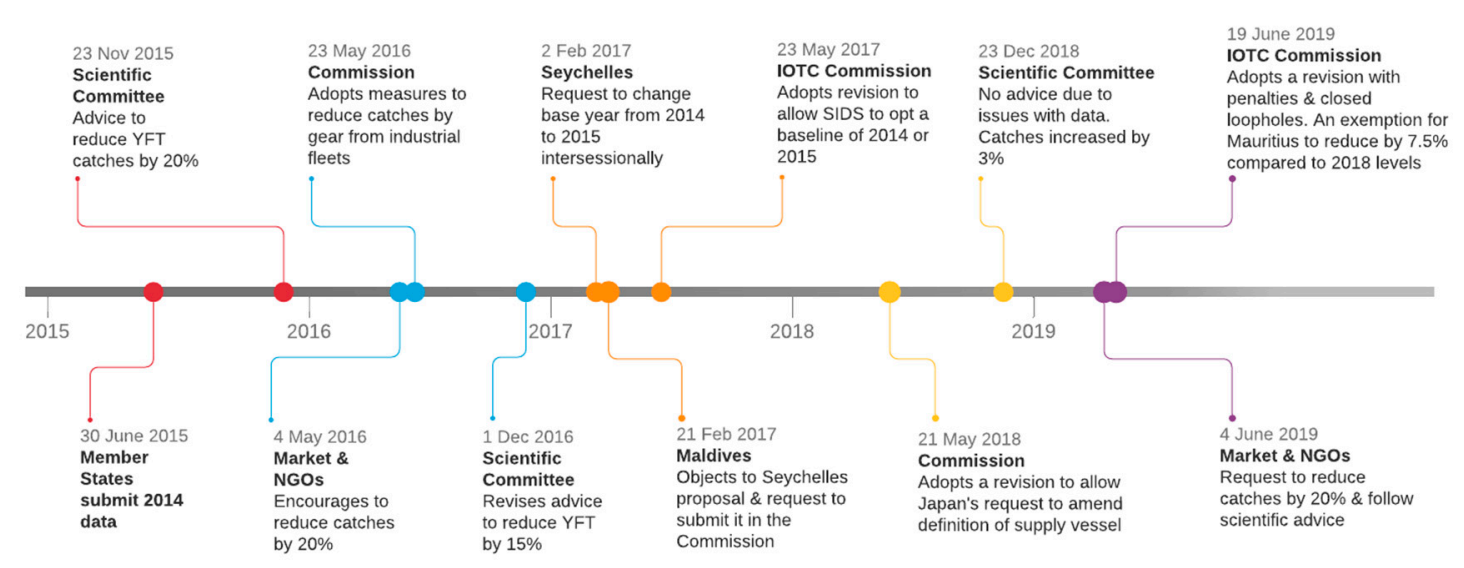

Figure 1. Indian Ocean Tuna Commission's yellowfin tuna reduction measures from 2015 to 2019.

IOTC is the only tuna RFMO with such a huge time gap between the data submission and decision-making. On average, the other tuna RFMOs usually make decisions within 4-7 months after data are submitted, as shown in Table 2. Member states in all the RFMOs except IOTC make decisions 
based on the previous year's data. Even though the data are submitted to IATTC, a month after the science committee, the commission staff utilize the real-time reporting from the purse seine fleet in the stock assessment. In IATTC, $85 \%$ of the landings come from these purse seine fleet [40]. On the other hand, where they have almost perfect allocation or rights-based management systems, decisions on the total allowable catch are made in lengthy intervals due to the lack of financial and capacity constraints. These decisions also face lengthy court battles, delaying their implementation [41]. However, the IOTC has the financial and capital resources to make decisions in a timely manner.

Table 2. Time frame of reporting of previous year's catch and effort data in different tuna RFMOs, scientific processes, and decision-making.

\begin{tabular}{cccc}
\hline RFMO & Data Submission Deadline & Scientific Committee & Commission \\
\hline IOTC & June & November & Following year May/June \\
ICCAT & July & September & November \\
WCPFC & April & August & November/December \\
CCSBT & April & August & October \\
IATTC & June & May & August \\
\hline
\end{tabular}

Thus, the credibility of an allocation mechanism is questionable, because even once established it would not be effective without reducing the time-gap between data submission, scientific analysis, and decision-making. The allocation would be based on a total allowable catch determined from two-year-old data, creating unnecessary uncertainties for parties to question the credibility and technical acceptability of the allocation mechanism.

\section{Scientific Barriers}

\section{Lowest Common Denominator}

Like other tuna RFMOs, IOTC scientific processes are hindered by a lack of accurate data, given a large proportion of the catch is landed by artisanal fishing vessels. Moreover, some of the industrial fleet also faces issues with reporting complete data for stock assessments in compliance with IOTC resolutions. For example, in $2019,72 \%$ of the nominal catches were fully or partially complete. The data reported are also of poor quality, which makes them difficult to use in stock assessments. For example, $30 \%$ of the data for tropical tuna are poorly reported, while $40-70 \%$ of the neritic tuna data are of poor quality [42]. Furthermore, the conservation and management measures as prescribed in the UNFSA are often slow and diluted in order to satisfy the lowest common denominator, as the decisions are mostly consensus-based. This is usually reinforced by claims of insufficient data or uncertain science, which is typical in tuna mis-management [43]. For example, one of the proposals adopted by the commission in 2018 on billfishes (Resolution 18/05) mandated all members of IOTC to collectively ensure that the billfish of the Indian Ocean (i.e., striped, black, and blue marlin and Indo Pacific sailfish) in any given year do not exceed either the Maximum Sustainable Yield (MSY) level or, in its absence, the lower limit of the MSY range of central values, as estimated by the scientific committee. The commission debated the feasibility of establishing a mechanism to collectively ensure that catches do not exceed the MSY, in the absence of an allocation for each country. The proposal was adopted by changing the text so that members "endeavor collectively" that all the catches of billfishes do not exceed the MSY. As shown in Table 3, the catches in 2016 of these species are substantially higher than the MSY levels, and nearly double in the case of black marlin. The IOTC has established a compliance management mechanism to monitor and review its member states' performance against the adopted conservation and management measures. Members are required to report on their progress of implementation and any compliance issues faced during the implementation of the conservation management measures. Without a mandated clear direction for its members, the adopted measure by the commission of simply having members endeavor to conserve and manage the bill fish stocks in the Indian Ocean is toothless. 
The perception of the general public of IOTC's failure in adopting conservation and management measures in line with the scientific committee's findings and to fulfill its mandate pose a question about the legitimacy of the organization.

Table 3. 2016 catches and the Maximum Sustainable Yield (MSY) in metric tonnes for each species, as advised by the scientific committee to the commission [44].

\begin{tabular}{ccc}
\hline Species & 2016 Catch (MT) & MSY (MT) \\
\hline Black Marlin & 17,829 & 9932 \\
Blue Marlin & 16,353 & 11,930 \\
Striped Marlin & 5299 & 3260 \\
Indo-Pacific Sailfish & 27,975 & 25,000 \\
\hline
\end{tabular}

\section{Political Barriers}

\subsection{Taiwan vs. China}

Since the introduction of the concept of "fishing entities" in UNFSA, many regional fisheries bodies have found solutions of one kind or another to include Taiwan, a province of China (as recognized by the United Nations), as a commission member and subsequently in the decision-making process [33]. All the solutions to this issue for fishery bodies to date have occurred outside the framework of the FAO or UN system. However, as an FAO body, the IOTC lies within the boundaries of the UN system. The IOTC is the only tuna RFMO that has so far failed to find a solution to incorporate Taiwan [33]. Presently, Taiwan participates in the IOTC as an "invited expert", which does not entitle any rights observed by its members or cooperating members. Taiwan is responsible for $16 \%$ of bigeye tuna, and its catches account for over four times that of other Chinese vessels in the Indian Ocean, so without their legitimate participation the commission is unable to function effectively. The possible recognition of Taiwan as a fishing entity in the IOTC would threaten the legitimacy of the "one China policy" in the UN, thus China-a member state of the IOTC —-would obstruct any move to recognize Taiwan more formally. This has the effect then of creating political barriers borne from institutional barriers, as described above with the FAO.

This situation has affected the allocation process as well, as both the proposals in the table have tried to find a resolution to the matter, but without much progress. For example, an information paper on allocation submitted by the EU in 2018 tried to include Taiwan in an allocation mechanism, proposing to define Taiwan as "long-term participating non-Contracting Parties (LPNCP). However, China rejected the definition during the 5th Technical Committee on Allocation Criteria in 2019. As long as the IOTC lies within the framework of the FAO as discussed, Taiwan will not be granted a seat at the table without China's formal endorsement, which is unlikely due to the geopolitical situation.

\subsection{Disputed Territories}

Apart from the China-Taiwan issue, several other disputes over sovereignty of various territories in the Indian Ocean (Table 4) also hinder the performance and cooperation potential of IOTC members. Based on sovereignty over these islands in the Indian Ocean, UK and France claim a vast EEZ and sizable extended continental shelf (United Nations Convention on the Law of the Sea of 1982 provides the framework to demarcate 12 nautical miles for territorial sea and further 200 nautical miles for the Exclusive Economic Zone (EEZ), giving full sovereignty for the living and non-living resources in the ocean space, seafloor, and underneath the seafloor to the island state, except for rocks. Furthermore, it also allows states to claim an exclusive jurisdiction over the extended continental shelf). These territories provide an EEZ of 0.6 million $\mathrm{km}^{2}$ to the United Kingdom and 2.7 million $\mathrm{km}^{2}$ to France, amounting to around $5.5 \%$ of the total IOTC area of competence, as shown in Table 3 . The EEZ of France in the Indian Ocean is almost nine times greater than its metropole [45]. 
Table 4. British and French territories in the Indian Ocean. Reconstructed based on data from [45-48].

\begin{tabular}{|c|c|c|c|c|c|c|}
\hline Territory & Claimed by & Contested by & Population & Land Area & $\begin{array}{l}\text { Claimed } \\
\text { EEZ }\left(\mathrm{km}^{2}\right)\end{array}$ & $\begin{array}{c}\text { Claimed } \\
\text { Shelf }\left(\mathrm{km}^{2}\right)\end{array}$ \\
\hline BIOT & UK & Mauritius & No permanent & 60 & 638,555 & 21,654 \\
\hline Crozet & France & Not contested & No permanent & 352 & 574,539 & 7449 \\
\hline Kerguelen & France & Not contested & No permanent & 7215 & 567,687 & 63,888 \\
\hline Mayotte & France & Comoros & 850,966 & 374 & 62,982 & 2179 \\
\hline Reunion & France & Not contested & 235,132 & 2512 & 315,071 & 595 \\
\hline $\begin{array}{l}\text { Saint-Paul and } \\
\text { Amsterdam }\end{array}$ & France & Not contested & No permanent & 62 & 509,014 & 164 \\
\hline Scattered Islands & France & $\begin{array}{l}\text { Mauritius, } \\
\text { Comoros and } \\
\text { Madagascar }\end{array}$ & No permanent & 44 & 622,706 & 3131 \\
\hline
\end{tabular}

These territorial claims have been one of the persistent issues in the IOTC. The matter has escalated following the advisory opinion of the International Court of Justice on the "legal consequences of the separation of the Chagos Archipelago from Mauritius in 1965", and the UN General Assembly's (UNGA) adoption of a resolution (Res: 73/295) affirming that Chagos Archipelago is an integral part of the territory of Mauritius, demanding that the United Kingdom unconditionally withdraw its colonial administration within six months [49]. In 2019, Mauritius asserted that the United Kingdom's participation in the IOTC be terminated as a coastal state and demanded IOTC to follow the UNGA's resolution, as IOTC lies within the UN framework [23]. The United Kingdom rejected Mauritius' claims and urged members to focus on fishery management measures rather than bilateral sovereignty disputes.

These sovereignty claims lead to lengthy interventions and a general lack of full legitimacy in the commission's positions and decisions. Mauritius and Comoros have argued that France and the UK should not be granted any allocation in respect to the disputed territories. France and the UK maintain their position that this is a domestic and bilateral issue and should not be discussed in the IOTC. Given that the IOTC members are often represented from fishery departments, the introduction of these complex geopolitical matters hinders the already complicated fisheries governance issues. However, without any headway in these "domestic and bilateral EEZ disputes", it would be difficult to achieve any systematic allocation process.

\subsection{Civil War and Conflicts}

Any legitimate allocation regime needs to be inclusive and equitable for it to remain stable. The allocation regimes in tuna RFMOs heavily depend on the level of historical fishing to determine the potential for future fishing opportunities. However, the criterion has been heavily contested by coastal countries who have not historically had a fishery but who have aspirations to develop one. Strikingly, another group of coastal states that has emerged from the negotiations in the Indian Ocean are countries that have had a fishery in the past, but, due to civil wars and internal conflicts, the fishery has been diminished or has been prevented from further development. For example, the ongoing Somali civil war and the recently subsided 23-year armed conflict in Sri Lanka substantially diminished their fishing opportunities in the past. Foreign fleets used this opportunity to fish illegally (i.e., without authorization from the Somali government or a formal access agreement) in the 0.78 million $\mathrm{km}^{2}$ productive Somali waters [50], increasing the historical catch of those flag states. Furthermore, the Sri Lankan government banned domestic fishing vessels from the north (which constituted around $20 \%$ to $25 \%$ of the national catch) to venture into the sea and even restricted fishing in most of their EEZ during the armed conflict period to mitigate insurgents and the transfer of weapons [51]. The negative economic impacts of conflict have been labelled as "development in reverse", recognizing the enormous difficulty that states may have in getting back to their previous conditions $[52,53]$. Populations, including fishers, get displaced and labor gets redeployed, resulting in economic counter insurgents, third party encroachments, and diminished fishing opportunities [53]. Somalia and Sri Lanka have raised these issues in TCAC meetings and demanded that the historical catch criteria 
will create a bias against these countries. Furthermore, Yemen, who is involved in a bitter civil war, has not taken part in these negotiations. The ongoing conflict in Yemen has resulted in huge losses in their fisheries sector [54], including the loss of jobs of around $93 \%$ of the total workers in the fisheries and industrial sector in the areas bound by the Red Sea. [55]. A key element in promoting cooperation on allocations is to ensure that no one is worse off in acting cooperatively than in acting individually [5], and for all parties to recognize that the process is fair, equitable, and just. However, there are disagreements on how these states with diminished fishing opportunities due to civil wars would be accommodated in an allocation process in the IOTC.

\subsection{Subsidies}

As indicated above, historical catch remains one of the contentious principles in the allocation mechanism. Countries with historically large fishing fleets were heavily subsidized, and they continue to subsidize today to remain competitive in the sector. Subsidies generally make fishing more profitable than it otherwise would be, thereby contributing to increasing effort and over-capacity, which can lead to the overfishing of the stock [56,57]. Using the game-theoretic concept of a double principle-agent problem, Bailey et al. [58] argued that fishing subsidies can undermine the conservation and management measures adopted by RFMOs. Moreover, fishing fleets that are subsidized will have ultimately lower costs and could offer lower prices to remain in the market and for market competitiveness. Furthermore, countries with subsidized fishing fleets will have an established catch history. For example, in 2018 China, the European Union, the Republic of Korea, Japan, and Thailand contributed around 51\% (18.26 billion USD) of the global estimated subsidy, spending 12.6 billion USD in 2018 for capacity-enhancing subsidies [59]. These countries caught $42 \%$ of the yellowfin tuna, $88 \%$ of the bigeye tuna, and $63 \%$ of the skipjack tuna in the Indian Ocean in 2018. Thus, subsidies pose a barrier for coastal developing states to create a historical fishing narrative to even access future fishing opportunities, particularly if historical catch is attributed to the flag state.

\section{Discussion}

For a multilateral organization such as the IOTC to govern effectively, the organization needs to be legitimate, credible, and stable. To succeed, the organization need not only fulfill its mandate under the convention or the agreement or other international laws, but must also fulfill the expectations and perceptions of the players involved in the decision-making processes of RFMOs. As shown in Figure 2, critical elements for the performance of an RFMO are a fair and equitable decision-making process, compliance, monitoring, control and surveillance, capacity to adapt (for example, to climate change, among other dynamic processes), memberships, the ability to include the aspirations of developing coastal states, transparency, allocation, and harvest strategies for species under the mandate of the commission [5,60-63]. However, in the case of IOTC, we have identified institutional, political, and scientific barriers that have impeded allocation negotiations (Figure 2). The issues identified in the paper raise questions about the future of the organization, including its credibility, stability, and legitimacy.

Cooperation on allocations is contingent on ensuring that no one is worse off in acting cooperatively than in acting individually [5] and avoiding conflict and uncertainty while maintaining fairness throughout the process [4]. However, this has proven difficult, as states have diverse fishery management objectives and are at different levels of fleet development and subsidization, especially in the IOTC. The relationship between the FAO and IOTC needs to be resolved to bring stability to the organization. The FAO played a crucial role in establishing the IOTC and facilitating the evolution of the organization. However, the IOTC has matured over the years, and there is no clear need for the FAO's direct involvement, as evident from their engagement in the IOTC internal processes over the last few years. The other four tuna RFMOs are independent but maintain a healthy relationship with FAO [32]. In fact, the FAO is often represented in the commission meetings of all the RFMOs as an observer, and contributes to capacity development programs through various projects run by these organizations. 
Cognizant of this difference, the FAO could take a leadership role in providing the required autonomy to the member states. The FAO could facilitate the process of transferring the organization to an independent body similar to all the other tuna RFMOs. If the IOTC is independent, the member states have the opportunity to operate similar to all the other tuna RFMOs, responsible only for the member states, including reporting, compliance, and financial and human resource management. Moreover, this could pave the way for a negotiation of a new agreement with modern fishery management concepts and addressing the membership of Taiwan. One of the newest RFMOs-the Southern Indian Ocean Fisheries Agreement (SIOFA), established in 2012-addressed the issue by including a provision in the main text of the treaty to allow the participation of fishing entities in subsidiary bodies and decision making [64]. Furthermore, this could also resolve the issues surrounding sovereignty and disputed territories, as discussed above. As the FAO lies within the UN system, the disputes over sovereignty continue to rear their ugly heads at the IOTC. On the contrary, countries which have lobbied in the UN system over the disputed territories might block the removal of the IOTC from the FAO system.

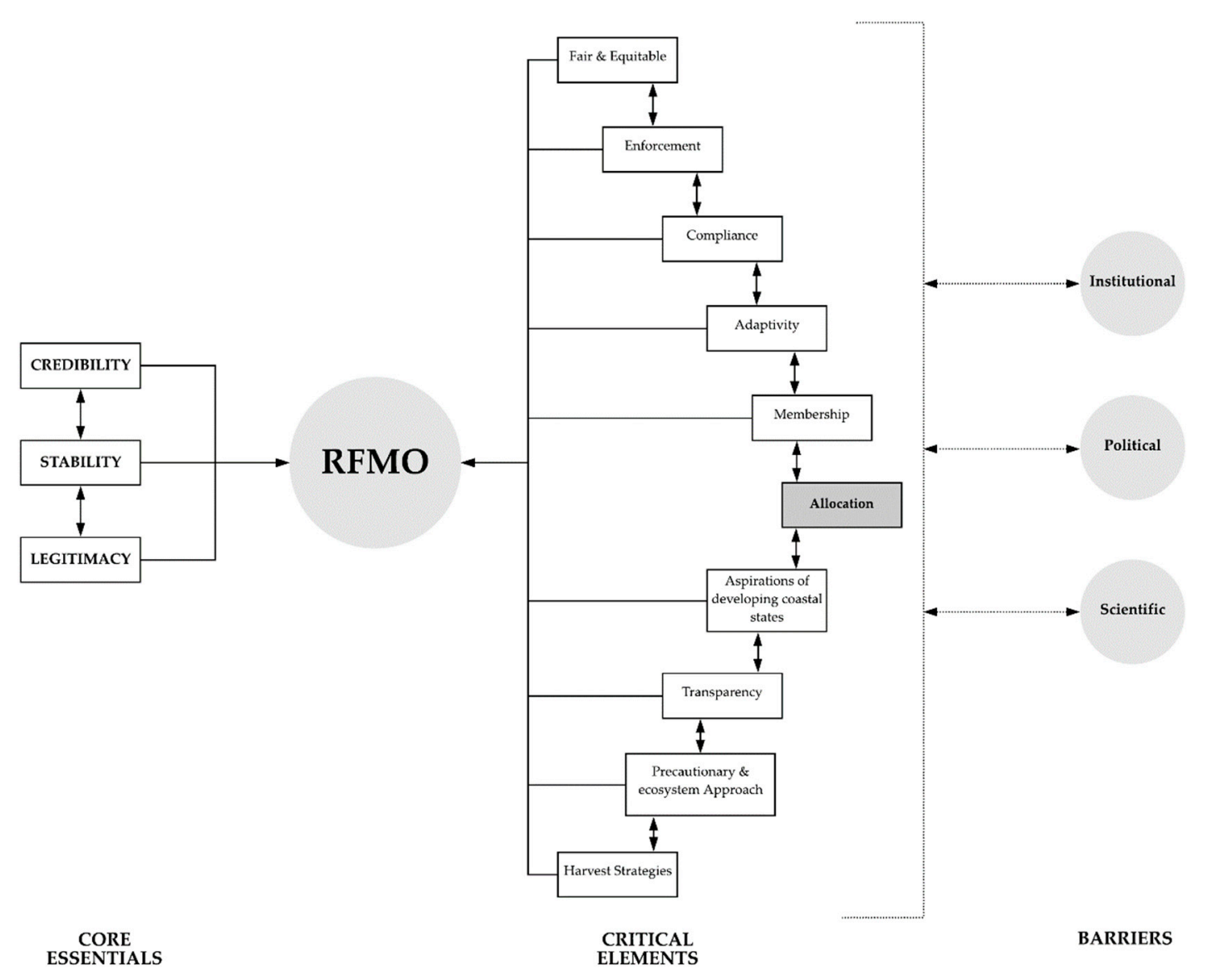

Figure 2. Core essentials and critical elements for an effective performance of Regional Fisheries Management Organizations and the barriers that prevent such effectiveness in the IOTC.

Subsequently, if the IOTC remains a "project" of FAO, there needs to be a more cohesive working relationship between the two organizations that addresses the concerns of both the parties in a timely manner. Given the sensitivities in international diplomacy around the issue of Taiwan [64], it would be a challenge to resolve the matter within the FAO system. This might also mean that one of the important fishing members in IOTC will not be involved in the negotiations nor its inclusion in the allocation table. Furthermore, the strained relationship with FAO has also blocked the progress in modernizing the agreement, as highlighted in the second performance review. Modernizing the agreement could open up the discussion on reducing the time gap between data submission, stock assessment, and 
decision-making. As illustrated, the time from data submission to decision-making in the IOTC is the longest in all the tuna RFMOs, and is already impacting the decision-making process. Tuna, being a highly migratory stock fished across many member countries with diverse fishing capacities, requires stock management decisions to be made in a timely manner.

However, member states opt for the lowest common denominator or delay the adoption of management measures, questioning the reliability of data. Data deficiency is not unique to the IOTC, but it is more challenging, mainly due to the high proportion of artisanal fisheries catches. From 2014-2018, artisanal fishing vessels caught around $48 \%$ of the total tropical tuna catch (skipjack tuna, yellowfin tuna, and bigeye tuna) [65]. In 2018, in the WCPFC, which manages the largest tropical tuna catches in the world, artisanal gears caught around of $14 \%$ of the tropical tuna catch [66]. Due to the characteristics of artisanal fisheries, it can be more difficult to monitor these catches compared to those of industrial vessels. The conventional stock assessments are usually based on costly and data-intensive methodologies, which are often inadequate to be implemented in small-scale or artisanal fisheries [67]. Furthermore, the industrial fishing vessels are also not immune from data issues. In 2019, the scientific committee revised the data reported by Spain for stock assessments, citing that the data submitted was implausible [20]. The IOTC needs to strengthen data reporting and invest in monitoring programs to assist coastal countries in developing capacity to collect data from artisanal fisheries. In fact, the IOTC has a meeting participation fund to facilitate developing coastal countries to participate in scientific and commission meetings. However, a broader capacity building fund could be established to develop the capacity of artisanal fishery data collection, such as the one developed in ICCAT.

The divide between coastal states and DWFNs and the adoption of conservation and management measures to satisfy the lowest common position, compounded with issues in implementation compliance and the enforcement of conservation and management measures, continue to plague the IOTC. If the IOTC intends to move forward with developing and operationalizing the allocation process, the negotiations have to move from the 5-day sitting of 32 member countries to bilateral and multilateral negotiations. As historical catch constitutes a huge proportion of the allocation proposals on the negotiation table, countries who have the financial capacity to continue to increase their fishing capacity and catch landings will continue to benefit from the current systems. Countries who have these capacities often use delaying tactics until there is a necessity (increase costs, reduced stock levels) to adopt a measure [68].

\section{Conclusions}

There are essential and critical elements for the effective performance of RFMOs, but as demonstrated for the case of the IOTC, barriers that impede the decision-making process limit the extent to which these elements can be realized. In this paper, the specific case of allocation has been highlighted. Though there are commonalities in tuna RFMOs, they should not be viewed in a single lens. Allocation negotiations in the IOTC have a long history, but progress remains slow. With the global pandemic of COVID-19, the IOTC TCAC has been reduced to a virtual sitting of a $2 \mathrm{~h}, 2$ day session. This would limit constructive discussion on the allocation framework, could make overcoming any of the barriers identified almost impossible, and could threaten the momentum of the cooperation recently observed in the developing coastal state block. The IOTC is the only RFMO that has attempted to implement a systematic allocation framework [12]. However, if there are no agreements on the institutional, political, and scientific barriers identified, the commission might end up with a pseudo-allocation process, just like all the other tuna-RFMOs, which is often unstable and which would lead to a general lack of compliance due to the inequities perceived by member states in the long term.

Author Contributions: Conceptualization, H.S. and M.B.; methodology, H.S. and M.B.; formal analysis, H.S.; writing, H.S. and M.B.; visualization, H.S. All authors have read and agreed to the published version of the manuscript. 
Funding: This research received no external funding.

Acknowledgments: H.S. and M.B. would like to thank the International Pole and Line Foundation for their funding to participate in the IOTC meetings. H.S. participated as an advisor to the Maldives delegation, and M.B. participated as an observer in the delegation of the International Pole and Line Foundation.

Conflicts of Interest: H.S. participated in IOTC meetings as a country delegate (advisor) and chairs the Committee on Administration and Finance in IOTC during the research period. H.S. worked and represented the Government of Maldives in IOTC meetings prior to his research.

\section{References}

1. Buchanan, A.; Keohane, R.O. The Legitimacy eof Global Governance Institutions. Ethics Int. Aff. 2006, 20, 405-437. [CrossRef]

2. Mautner-Markhof, F. Processes of International Negotiations; Routledge: Abingdon, UK, 2019.

3. Aradau, C.; Huysmans, J. Assembling credibility: Knowledge, method and critique in times of "post-truth". Secur. Dialogue 2019, 50, 40-58. [CrossRef]

4. Ostrom, E. Governing the Commons: The Evolution of Institutions for Collective Action; Cambridge University Press: Cambridge, UK, 1990; Volume 32.

5. Lodge, M.W.; Anderson, D.; Løbach, T.; Munro, G.; Sainsbury, K.J.; Willock, A. Recommended Best Practices for Regional Fisheries Management Organizations Report of an Independent Panel to Develop a Model for Improved Governance by Regional Fisheries Management Organizations; Chatham House: London, UK, 2007.

6. Hanich, Q.; Ota, Y. Moving Beyond Rights-Based Management: A Transparent Approach to Distributing the Conservation Burden and Benefit in Tuna Fisheries. Int. J. Mar. Coast. Law 2013, 28, 135-170. [CrossRef]

7. Bailey, M.; Ishimura, G.; Paisley, R.; Rashid Sumaila, U. Moving beyond catch in allocation approaches for internationally shared fishstocks. Mar. Policy 2013, 40, 124-136. [CrossRef]

8. Havice, E.; Campling, L. Shifting Tides in the Western and Central Pacific Ocean Tuna Fishery: The Political Economy of Regulation and Industry Responses. Glob. Environ. Polit. 2010, 10, 89-114. [CrossRef]

9. Yeeting, A.D.; Bush, S.R.; Ram-Bidesi, V.; Bailey, M. Implications of new economic policy instruments for tuna management in the Western and Central Pacific. Mar. Policy 2016, 63, 45-52. [CrossRef]

10. FAO. The State of World Fisheries and Aquaculture (SOFIA) 2016; FAO: Rome, Italy, 2016; ISBN 9789251091852.

11. Telesca, J.E. Red Gold: On the Global Politics of Regulating Marine Life; New York University: New York, NY, USA, 2014; ISBN 1303764490.

12. Seto, K.; Galland, G.; McDonald, A.; Abolhassani, A.; Azmi, K.; Sinan, H.; Timmiss, T.; Bailey, M.; Hanich, Q. Resource allocation in transboundary tuna fisheries: A global analysis. AMBIO Manuscr. Press 2020.

13. Allen, R.L.; Joseph, J.; Squires, D. Conservation and Management of Transnational Tuna Fisheries; Wiley-Blackwell: Hoboken, NJ, USA, 2010; ISBN 9780813805672.

14. European Commission Bilateral Agreements with Countries outside the EU. Available online: https: //ec.europa.eu/fisheries/cfp/international/agreements_en (accessed on 14 May 2020).

15. Mwikya, S.M. Fisheries Access Agreements: Trade and Development Issues; International Centre for Trade and Sustainable Development (ICTSD): Geneva, Switzerland, 2006; ISBN 1563-0544.

16. FAO. FAOSTAT. Available online: http://www.fao.org/faostat/en/\#data/CL (accessed on 1 April 2019).

17. Robinson, J.; New, A.L.; Popova, E.E.; Srokosz, M.A.; Yool, A. Far-field connectivity of the UK's four largest marine protected areas: Four of a kind? Earth's Futur. 2017, 5, 475-494. [CrossRef]

18. Noye, J.; Mfodwo, K. First steps towards a quota allocation system in the Indian Ocean. Mar. Policy 2012. [CrossRef]

19. Abolhassani, A. Tuna fisheries and geopolitical change: Coastal and fishing country tensions resurface at the Indian Ocean Tuna Commission. Aust. J. Marit. Ocean Aff. 2017, 10, 35-41. [CrossRef]

20. IOTC. Report of the 22nd Session of the IOTC Scientific Committee; Indian Ocean Tuna Commission: Victoria, Seychelles, 2019.

21. IOTC. Report of the 21st Session of the Indian Ocean Tuna Commission; Indian Ocean Tuna Commission: Victoria, Seychelles, 2017.

22. IOTC. Report of the 21st Session of the IOTC Scientific Committee; Indian Ocean Tuna Commission: Victoria, Seychelles, 2018. 
23. IOTC. Report of the 23rd Session of the Indian Ocean Tuna Commission; Indian Ocean Tuna Commission: Victoria, Seychelles, 2019.

24. Macfadyen, G.; Defaux, V. Scoping Study of Socio-economic Data and Indicators of IOTC Fisheries; Indian Ocean Tuna Commission: Victoria, Seychelles, 2019.

25. IOTC Technical Committee on Allocation Criteria Meetings. Available online: https://iotc.org/meetings/ search?s=\&field_meeting_tid_i18n=112\&field_meeting_year_tid=All (accessed on 27 July 2020).

26. IOTC. 5th Session of the Technical Committee on Allocation Criteria; Indian Ocean Tuna Commission: Victoria, Seychelles, 2019.

27. IOTC. Report of the Third Technical Committee on Allocation Criteria; Indian Ocean Tuna Commission: Kish, Iran, 2016.

28. Andriamahefazafy, M.; Bailey, M.; Sinan, H.; Kull, C.A. The paradox of sustainable tuna fisheries in the Western Indian Ocean: Between visions of blue economy and realities of accumulation. Sustain. Sci. 2019. [CrossRef]

29. FAO. Report of the Council of FAO; FAO: Rome, Italy, 1967.

30. Kambona, J.; Marashi, S. Process for the Establishment of the Indian Ocean Tuna Commission; Food and Agriculture Organisation of the United Nations: Rome, Italy, 1996.

31. IOTC. Report of the Third Special Session of the Indian Ocean Tuna Commission; Indian Ocean Tuna Commission: Goa, India, 2006.

32. Hurry, G. Cost and Benefit of the Indian Ocean Tuna Commission (IOTC) within and outside of the Food and Agriculture Organisation (FAO); Indian Ocean Tuna Commission: Victoria, Seychelles, 2016.

33. Edeson, W.R. An International Legal Extravaganza in the Indian Ocean: Placing the Indian Ocean Tuna Commission outside the Framework of FAO. Int. J. Mar. Coast. Law 2007, 22, 485-515. [CrossRef]

34. Undercurrent News. IOTC head 'forced to resign' amid links to videotaped executions. Undercurrent News, 9 December 2015.

35. IOTC. Report of the 20th Session of the Indian Ocean Tuna Commission; Indian Ocean Tuna Commission: Victoria, Seychelles, 2016.

36. IOTC. Report of the 2nd IOTC Performance Review; Indian Ocean Tuna Commission: Victoria, Seychelles, 2016.

37. IOTC. Draft IOTC Agreement Text; Indian Ocean Tuna Commission: Victoria, Seychelles, 2019.

38. IOTC. Agreement for the Establishment of the Indian Ocean Tuna Commission; Indian Ocean Tuna Commission: Victoria, Seychelles, 1993.

39. IOTC. IOTC Circular 2017-13 Communication from Ministry of Agriculture and Fisheries, Seychelles; Indian Ocean Tuna Commission: Victoria, Seychelles, 2017.

40. IATTC. The Tuna Fishery in the Eastern Pacific Ocean in 2019; Inter-American Tropical Tuna Commission: La Jolla, CA, USA, 2020.

41. Hersoug, B. "After all these years"-New Zealand's quota management system at the crossroads. Mar. Policy 2018, 92, 101-110. [CrossRef]

42. IOTC. Report on IOTC Data Collection and Statistics; Indian Ocean Tuna Commission: Victoria, Seychelles, 2019.

43. Telesca, J.E. Consensus for Whom? Gaming the Market for Atlantic Bluefin Tuna through the Empire of Bureaucracy. Cambridge J. Anthropol. 2015, 33, 49-64. [CrossRef]

44. IOTC. Report of the 20th Session of the IOTC Scientific Committee; Indian Ocean Tuna Commission: Victoria, Seychelles, 2017.

45. Bouchard, C.; Crumplin, W. Two faces of France: 'France of the Indian Ocean'/'France in the Indian Ocean'. J. Indian Ocean Reg. 2011, 7, 161-182. [CrossRef]

46. Claus, S.; De Hauwere, N.; Vanhoorne, B.; Deckers, P.; Dias, F.S.; Hernandez, F.; Mees, J. Marine Regions: Towards a Global Standard for Georeferenced Marine Names and Boundaries. Mar. Geod. 2014, 37, 99-125. [CrossRef]

47. INED Population by Region and Department. Available online: https://www.ined.fr/en/everything_about_ population/data/france/population-structure/regions_departments/ (accessed on 20 June 2019).

48. Foreign and Commonwealth Office. The Overseas Territories-Security, Success and Sustainability; Foreign and Commonwealth Office: London, UK, 2012.

49. United Nations UN General Assembly Resolution 73/295; United Nations: New York, NY, USA, 2019.

50. Devlin, C.; Glaser, S.M.; Villegas, C.; Poinsattem, N. Rough Seas: The Causes and Consequences of Fisheries Conflict in Somali Waters; One Earth Future: Broomfield, CO, USA, 2020. 
51. Siluvaithasan, A.S.; Stokke, K. Fisheries under fire: Impacts of war and challenges of reconstruction and development in Jaffna fisheries, Sri Lanka. Nor. Geogr. Tidsskr. Nor. J. Geogr. 2006, 60, 240-248. [CrossRef]

52. Collier, P.; Elliott, V.L.; Hegre, H.; Hoeffler, A.; Reynal-Querol, M.; Sambanis, N. Breaking the Conflict Trap; The World Bank: Washington, DC, USA, 2003.

53. Hendrix, C.S.; Glaser, S.M. Civil conflict and world fisheries, 1952-2004. J. Peace Res. 2011, 48, 481-495. [CrossRef]

54. Mundy, M. The Strategies of the Coalition in the Yemen War: Aerial Bombardment and Food War Aerial Bombardments on Sana'a; World Peace Foundation: Cambridge, MA, USA, 2016.

55. Elayah, M.; Schulpen, L.; Yaseen, T. Fishing during war? The impact of war on Yemeni fisheries. In Fisheries Conflict: Case Studies; Fisheries Conflict Research Consortium: Broomfield, CO, USA, 2019.

56. Bailey, M.; Willis, C.; Sinan, H. Public resource, private profit: Investigating tuna subsidies in the IOTC area of compliance. In Proceedings of the IOTC Scientific Committee, Mahé, Seychelles, 3-7 December 2018; Indian Ocean Tuna Commission: Victoria, Seychelles, 2018.

57. Sumaila, U.; Khan, A.; Dyck, A.; Watson, R.; Munro, G.; Tydemers, P.; Pauly, D. A Bottom-Up Re-Estimation of Global Fisheries Subsidies; National Bureau of Economics Research: Cambridge, MA, USA, 2010; Volume 12.

58. Bailey, M.; Miller, A.M.M.; Bush, S.R.; van Zwieten, P.A.M.; Wiryawan, B. Closing the Incentive Gap: The Role of Public and Private Actors in Governing Indonesia's Tuna Fisheries. J. Environ. Policy Plan. 2016, 18, 141-160. [CrossRef]

59. Sumaila, U.R.; Ebrahim, N.; Schuhbauer, A.; Skerritt, D.; Li, Y.; Kim, H.S.; Mallory, T.G.; Lam, V.W.L.; Pauly, D. Updated estimates and analysis of global fisheries subsidies. Mar. Policy 2019, 109, 103695. [CrossRef]

60. Haas, B.; McGee, J.; Fleming, A.; Haward, M. Factors influencing the performance of regional fisheries management organizations. Mar. Policy 2020, 113, 103787. [CrossRef]

61. Leroy, A.; Morin, M. Innovation in the decision-making process of the RFMOs. Mar. Policy 2018, 97, 156-162. [CrossRef]

62. Cullis-Suzuki, S.; Pauly, D. Failing the high seas: A global evaluation of regional fisheries management organizations. Mar. Policy 2010, 34, 1036-1042. [CrossRef]

63. Clark, N.A.; Ardron, J.A.; Pendleton, L.H. Evaluating the basic elements of transparency of regional fisheries management organizations. Mar. Policy 2015, 57, 158-166. [CrossRef]

64. Scanlon, Z. Incorporating Taiwan in international fisheries management: The southern indian ocean fisheries agreement experience. Ocean Dev. Int. Law 2017, 48, 35-51. [CrossRef]

65. IOTC. IOTC Datasets. Available online: https://iotc.org/data/datasets (accessed on 2 December 2019).

66. Williams, P.; Read, C. Overview of Tuna Fisheries in the WCPO, Including Economic Conditions-2018. In Proceedings of the 15th Regular Session of the Scientific Committee, Pohnpei, Micronesia, 12 August 2019.

67. Pita, C.; Villasante, S.; Pascual-Fernández, J.J. Managing small-scale fisheries under data poor scenarios: Lessons from around the world. Mar. Policy 2019, 101, 154-157. [CrossRef]

68. Libecap, G. Open-Access Losses and Delay in the Assignment of Property Rights; National Bureau of Economic Research: Cambridge, MA, USA, 2007.

(C) 2020 by the authors. Licensee MDPI, Basel, Switzerland. This article is an open access article distributed under the terms and conditions of the Creative Commons Attribution (CC BY) license (http://creativecommons.org/licenses/by/4.0/). 